\title{
Cytotoxic Activity of Endemic Astragalus argaeus Boiss. from Turkey ${ }^{\dagger}$
}

\author{
Sevil Albayrak ${ }^{1, *}$ and Onur Kaya ${ }^{2}$ \\ 1 Biology Department, Science Faculty, Erciyes University, Kayseri 38039, Turkey \\ 2 Graduate School Natural Applied Science, Erciyes University, Kayseri 38039, Turkey; \\ hatkoyonurr@gmail.com \\ * Correspondence: salbayrak@erciyes.edu.tr; Tel.: +90-352-207-66-66 \\ + Presented at the 2nd International Conference on Natural Products for Cancer Prevention and Therapy, \\ Kayseri, Turkey, 8-11 November 2017.
}

Published: 10 November 2017

\begin{abstract}
Astragalus L. is the largest genus in the family Leguminosae with over 3000 species and is represented in Turkey by 445 species, of which 224 are endemic. Several Astragalus species have many biological properties such as hepatoprotective, immunostimulant, antiviral, anti-aging, antitumor, antioxidant, antimicrobial, antimalarial, antileshmanial, antiperspirant, antiinflammatory, diuretic and tonic. The aim of this research was the investigation of the cytotoxic activities of extracts obtained from underground and aerial parts of Astragalus argaeus Boiss. on a human breast cancer cell line (MCF-7). The cytotoxic effects of extracts on MCF-7 (human breast cancer cell lines) and fibroblast cells during 24 and $48 \mathrm{~h}$ were determined by 3-(4,5-dimethyl thiazol2-yl)-2,5-diphynyl tetrazolium bromide (MTT) assay. The extracts showed weak cytotoxic activity on MCF-7 during $24 \mathrm{~h}$. To the best of our knowledge, this study is the first report on cytotoxic activity of $A$. argaeus.
\end{abstract}

Keywords: Astragalus argaeus; cytotoxic activity; MCF-7

Acknowledgement: This work was supported by the Research Fund of the University of Erciyes. Project number is FYL-2014-5072.

(C) 2017 by the authors. Licensee MDPI, Basel, Switzerland. This article is an open access article distributed under the terms and conditions of the Creative Commons Attribution (CC BY) license (http://creativecommons.org/licenses/by/4.0/). 